\title{
Measuring Educational Liberalisation. A Global Analysis of GATS
}

Antoni Verger. Universiteit van Amsterdam

\begin{abstract}
In this article, we examine the process of trade liberalisation of educational services in the framework of the General Agreement on Trade in Services (GATS) of the World Trade Organisation (WTO). Specifically, we analyse the factors that influence the undertaking of commitments on educational liberalisation by the member countries of the WTO. The text is divided into three parts. In the first, we examine in detail the methodology of GATS negotiation. Second, in order to measure the degree of liberalisation of educational services in the countries we construct an index called EduGATS. Finally, we review and analyse the commitments on liberalisation consolidated by member countries in terms of educational services. The sources of the primary data are the lists of commitments on services of the members of the WTO, interviews with delegations from member countries, documents on the position of various delegations and documents from the WTO Council for Trade in Services.
\end{abstract}

Keywords: GATS, WTO, liberalisation, privatisation, education, EduGATS, development.

\section{Introduction $^{1}$}

During the 1990s, many free trade agreements that contemplated "educational services" as a product able to be traded on an international scale were reached. Of all these, the only one of a multilateral type is the General Agreement on Trade in Services (GATS) of the World Trade Organisation (WTO). At present, the 150 member countries of the WTO are negotiating the liberalisation of educational services - and other types of services - in the framework of the Doha Round. Even so, the liberalisation of educational services in the GATS framework took its first steps during the Uruguay Round of GATT (1986-1994), when 28 countries established the first commitments on educational liberalisation in the framework of a multilateral trade agreement ${ }^{2}$.

The introduction of education into the system of rules on international trade has opened an interesting debate in the field of social sciences that has led to several research projects and theoretical essays often centred on the effects of trade liberalisation on educational systems. ${ }^{3}$ Our research, rather than adopting the

\footnotetext{
${ }^{1}$ This article is part of the project "Beyond targeting: Education, development and the fight against poverty in the Southern Cone. Analysis of the applications of the new global political agenda in the region". (I+D 2005-2008). Reference SEJ-04235.

${ }^{2}$ It was decided to create the WTO in this round of negotiations.

${ }^{3}$ The GATS promotes trade liberalisation. This shouldn't be confused with internal liberalisation. The former means to open local markets to foreign competition. The later means promoting the competition at
} 
perspective of the analysis of the effects, is interested in the causes and the rationale of the liberalisation policies. Specifically, the research focuses on the factors that influence the establishment of commitments on liberalisation in the area of educational services within the GATS framework. Our lines of hypotheses in this respect point to factors that influence the establishment of commitments on liberalisation in the educational sector. These are the economic inequalities between member countries, specific characteristics of these countries' educational systems (level of privatisation of educational spending, weight of the private sector, among others) and the date these countries joined the WTO. $^{4}$

In order to test these hypotheses, first we will penetrate the architecture and contents of the GATS. Specifically we will explain its aims and its negotiation methodology, we will interpret the content of its main articles and put forward the main political implications of the agreement. Second, we will prepare - and defend the need to prepare - a new index with which to measure the degree of commitment on educational liberalisation undertaken by member countries of the WTO. Third, we apply thins new index to analyse the factors that influence the liberalisation of educational services through qualitative and statistical correlation techniques. When making this analysis, we will focus on the consolidated commitments on liberalisation on the part of WTO member countries. We will not consider the provisional results of the Doha Round, as this round has not yet finished and, consequently, new commitments have not arisen at the multilateral level.

\section{Brief introduction to GATS and the negotiating process}

The GATS is one of the main agreements to have come under the WTO. In fact, this agreement has been called "the most important event in the system of multilateral trade since GATT came into force in 1948" (OMC 1999: p.1). This is due, to a great extent, to the economic importance of the services sector in the world economy: at present, services represent the $71 \%$ of the GDP in developed countries and $19 \%$ of global world trade (OMC 2001). The aim of GATS is "to establish a multilateral framework of principles and rules for trade in services with a view to the expansion of such trade under conditions of transparency and progressive liberalization and as a means of promoting the economic growth of all trading partners and the development of developing countries" (GATS Preamble). ${ }^{5}$

the national level. Nevertheless, in some cases, trade liberalisation policies have implied internal liberalisation.

${ }^{4}$ The hypotheses are briefly justified in the third section of the article.

${ }^{5}$ In: http://www.wto.org/English/docs_e/legal_e/26-gats_01_e.htm. Access date: 12/03/06. 
GATS contemplates the liberalisation of twelve service sectors, among which are educational services. ${ }^{6}$ These services, as with the other sectors, are not negotiated "in a block" as a whole sector, but in various sub sectors. Specifically, the educational sub sectors are: 1) primary education; 2) secondary education; 3) higher education; 4) adult education; and 5) other educational services.

The architecture of GATS is more complex than that of trade agreements on goods, due to the technical difficulties associated with the commercialisation of services - we should take into account that services are usually consumed where they are produced and are both produced and consumed simultaneously (Francois \& Wooton 2000). ${ }^{7}$ Given these difficulties, it has been established that there are four modes of commercialising services. These are: 1) Cross-border supply: provision of a service between countries at a distance. In the case of education, this mode is seen in e-learning or, in general, in distance learning programmes; 2) Consumption abroad: the consumer - in our case the student - travels to another country to access the service; 3) Commercial presence: the service company sets up a subsidiary abroad. For example, a university sets up a campus in another country; 4) Presence of natural persons: a professional (for instance, a researcher or a teacher) travels to a foreign country to provide a service. The liberalisation of service sub sectors is negotiated on the basis of these four modes, hence markets may be opened in one of the modes but not in the other three.

Additionally, we should point out that the liberalisation of services stipulated by GATS means the establishment of commitments on trade opening with reference to two articles: National Treatment and Market Access. The acquisition of commitments on liberalisation in terms of National Treatment means accepting that foreign companies benefit from treatment 'not less favourable' than that given to domestic companies. This implies that foreign suppliers cannot be discriminated against. While the commitments on Market Access means the elimination of barriers (rules, regulations laws, etc.) that hinder the entrance of foreign service providers in the domestic market ${ }^{8}$. Additionally

\footnotetext{
${ }^{6}$ These are: 1. Services provided to companies; 2. Communications services; 3. Engineering and construction services; 4. Distribution services; 5. Educational services; 6. Services related to the environment; 7. Financial services; 8. Health-care services; 9. Tourism and travel services; 10 . Cultural, sports and leisure services; 11 Transport services; 12 . "Others".

${ }^{7}$ The GATS constitution process is a key element to understand the complexity of the final architecture of the Agreement. The first proposal of the services agreement, placed by the US during the Uruguay Round, was very ambitious and, consequently, highly contested by Southern countries. To balance the interests of the majority of Member countries in the services area, they had to introduce several flexibilities and exceptions in the Agreement rules (Drake \& Nicolaidis 1992).

${ }^{8}$ There are six limitations which may be maintained /eliminated in Market Access: a) Number of services suppliers which are allowed access; b) Value of transactions or activity; c) Total number of service transactions or total sum of service production; d) Total number of natural persons who may be employed in a sector or by a specific supplier; e) Specific type of legal form or personality of suppliers; and f) Establishment of specific percentages of participation for foreign capital or the total value of foreign investments. Referring to National Treatment, countries can eliminate or maintain an unlimited number of
} 
there are a series of general terms not subject to negotiation. This would be the case with the obligations known as Most Favoured Nation or Transparency. ${ }^{9}$

In short GATS, in contrast to other WTO agreements, is not a closed agreement. Rather, it is a legal framework and a system of rules that allow WTO member countries to adopt commitments on trade liberalisation by means of successive negotiating rounds. On paper, GATS only obliges member countries to participate in negotiations; it does not oblige them in the process of such negotiations to liberalise their services. We now look at various relevant issues to better understand the logic of GATS and the negotiating process.

\section{Methodology of negotiation}

GATS negotiations take place in the framework of the Council of Trade in Services of the WTO (Larsen, Martin \& Morris 2002). The trade liberalisation process (specifically, MA and NT commitments) is negotiated based on the method of demand-offer. It means that the negotiating process comprises two key phases: the demands phase and the offers phase. During the demands phase, each country can make applications for liberalisation to other members. These demands refer to service sectors or sub sectors, although on occasions also to horizontal commitments (those related to issues that are transversal to the sectors such us specific modes of supply, foreign direct investment, etc.), which countries would like to export with a more favourable treatment. Neither the WTO Secretariat nor the countries that are not affected by the demand are aware of their content, unless the applying country makes this public. Once the demands have been made, members hold consultations between themselves with the aim of profiling the first offers. This leads to the offers phase, when countries respond to demands. In this phase, countries have to present a list in which they include the commitments on liberalisation that they accept will be established in various sectors. This document comprises a project of list of commitments on liberalisation that can be modified during negotiations. In this phase, in contrast to the previous, the lists are available to all members of the WTO, although they are not necessarily available to the general public. The publication of these lists depends, once again, on the willingness of the country that has prepared them.

limitations. The WTO Secretariat points out eight of them (WTO, 2000): a) Taxes and levies; b) Subsidies and grants; c) Other financial restrictions; d) Requirements on nationality; e) Requirements on residency; f) Qualifications, licences, standards; g) Requirements on registration; and h) Requirements on authorisation.

9 The MFN rule stipulates that each member will immediately and unconditionally assign service suppliers of a foreign country a treatment no less favourable than that given to service suppliers of any other member country, while transparency obliges countries to guarantee service suppliers access to information related to trade in services (laws, regulations, rules, etc.). The Members can establish exceptions to this rule that, theoretically, should last ten years at the most. 
During the period of the negotiating round, countries usually negotiate among themselves bilaterally. The round finishes when members present a definitive list of offers. All member countries are obliged to submit a list of commitments on liberalisation, but they do not have to include improvements with respect to the previous list, nor new commitments on liberalisation. For this reason, the GATS negotiating process is considered flexible. The flexibility of the agreement is not just a casual feature: during the Uruguay Round, most of the Southern countries - given that they are not overly competitive on trade in services - accepted the constitution of GATS with the condition that they were not forced to liberalise their services (Drake \& Nicolaidis 1992).

Nevertheless, flexibility as the main principle behind the agreement was fiercely questioned in 2005 by certain delegations of the WTO, mainly from the richest countries, who blamed the slow pace of service negotiations on "the excessive flexibility" in the methodology applied to negotiating the agreement (WTO 2005b). For this reason, at the latest meetings of the Council on Trade in Services and, especially, the VI Ministerial Conference of the WTO (Hong Kong, December 2005), a series of countries led by the EU exerted pressure-with relative success - to modify the negotiating modalities of the GATS (Khor 2005) ${ }^{10}$.

\section{Trade liberalisation: a one-way street}

The GATS has the aim of deepening and accelerating trade liberalisation in the services area. In line with this principle, the agreement contemplates the possibility that, at any moment, countries may introduce new commitments on their lists -irrespective of the development of the negotiations underway. In contrast, the agreement establishes hurdles to the withdrawal of commitments already established. With regard to this question, article XXI of GATS establishes that: a) The members may not withdraw their commitments until after three years have passed since their undertaking, b) The modification has to be notified at least three months in advance, and c) the members affected by the modification may file a lawsuit by means of which it may be ruled that a country modifying a list has to compensate those affected. Due to these rules, the GATS effectively lock in those who sign up to them (Robertson \& Dale 2003b).

Another reason why taking commitments in the framework of GATS is especially transcendent is related to the lack of definition of several GATS norms (such as the

\footnotetext{
${ }^{10}$ Initially the EU brought pressure to bear to introduce benchmarks in the negotiating rounds, so that countries would have to liberalise a minimum number of service sub-sectors in each round. Finally the VI Ministerial Conference of the WTO decided to introduce changes in the forms of negotiation of GATS, although it rejected benchmarking, mainly due to pressure exercised by various Southern countries (Khor 2005b). Among other changes, they reinforced the plurilateral perspective in the negotiation of the agreement (WTO 2005b).
} 
Emergency Safeguard Mechanisms) ${ }^{11}$ or the Domestic Regulation disciplines (Abugattas 2006).

\section{Reading the lists of commitments}

The lists of commitments inform us about the degree of opening up to trade that the member countries assume in each of the various service sectors. Concretely, the lists specify the limits that the countries decide to maintain or eliminate in the area of National Treatment and Market Access ${ }^{12}$. Additionally, the commitments and limitations are expressed in terms of each of the different modes of trade (cross-border supply; consumption abroad; trade presence; presence of natural persons).

Reading the lists is complex, not only because of the number of items that are included, but because the different headings are filled following different logics. On the one hand, the column related to the services sectors is filled using a method of positive list, that is, the lists include the names of the sectors and sub sectors which the countries decide to liberalise. On the other hand, the columns dealing with Market Access and National Treatment are filled using the method of negative list, so that we interpret that liberalisation is total when the box is empty or the entry reads "none", while no type of commitment is acquired if the entry reads "not binding". Even so, liberalisation is not a question of all or nothing; it can be occur gradually. In the event of wanting to establish limitations on liberalisation, this has to be specified clearly in the list. Finally, it should be noted that the lists contain a first heading entitled "horizontal commitments" in which transversal limitations are included, that is, limitations that are applied to all sectorial commitments. It is interesting to observe that the technical complexity of the establishment of commitments - along with confusion in the categorisation of services established by the WTO - has led some delegations to make commitments on services that, in fact, they had never intended to liberalise (Gould 2004).

To illustrate how this methodology is put into practice, Table 1 shows a section of a fictitious list. Here, country X liberalises the sub sector of primary education in the following way: a) Market Access: without commitments in mode 1 and in mode 4, total opening up in mode 2 and as regards mode 3, this states that domestic capital should comprise at least $25 \%$ of the investment; b) National Treatment: total opening up in modes 1 and 2, opening up in mode 3, although this states that the foreign provider will

\footnotetext{
11 Article $\mathrm{X}$ of GATS stipulates that member countries have to negotiate Emergency Safeguard Mechanisms (ESM), which would allow them a test period in the liberalisation of various sectors. Hence if a member is not satisfied with liberalisation and justifies this in a convincing manner to the Services Council, they may withdraw certain commitments. Nevertheless an agreement has still not been reached on this issue and the ESM does not exist (Jawara \& Kwa 2004; Nielson 2003).

${ }^{12}$ Additional commitments may be established, although so far no country has established any in the field of education. An example of additional commitments in education would be licensing facilities.
} 
not have rights to public subsidies, and without commitments in mode 4. Finally, no additional commitments are made.

Table 1. Example of a list of commitments

\begin{tabular}{|c|c|c|c|}
\hline \multicolumn{4}{|c|}{ 5. Educational Services (Country X) } \\
\hline & Market Access & National Treatment & $\begin{array}{c}\text { Additional } \\
\text { commitments }\end{array}$ \\
\hline $\begin{array}{l}\text { A. - Primary } \\
\text { education } \\
(\text { Country X) }\end{array}$ & $\begin{array}{l}\text { 1) Unbound } \\
\text { 2) None } \\
\text { 3) } 25 \% \text { of the capital has to } \\
\text { be domestic } \\
\text { 4) Unbound }\end{array}$ & $\begin{array}{l}\text { 1) None } \\
\text { 2) None } \\
\text { 3) None. Unbound for subsidies } \\
\text { 4) Unbound }\end{array}$ & \\
\hline
\end{tabular}

\section{Measuring the degree of educational liberalisation}

Once we know the logic behind the lists of commitments and the way they work, we have the necessary elements to calculate the degree of liberalisation indicated by these lists. Carrying out these calculations is essential due to the fact that our hypotheses are tested at two analytical levels. In the first, we observe the relation of the independent variables (economic development of the countries, characteristics of the educational systems, date of joining the WTO) with the establishment-or absence of establishment - of liberalisation commitments in the educational sector from member countries. At the second level of analysis, we observe the relation between the same explicative variables with the degree of commitment to liberalisation in the educational sector. In the latter case, we only analyse those countries that have actually established commitments within the educational sector. The second case means having to effectively measure degree of commitments. As this measurement is not usually made very precisely, we have had to construct a new index, which we call EduGATS.

\section{Calculation of EduGATS ${ }^{13}$}

When calculating EduGATS, we take into account the following factors: a) The educational sub sectors committed; b) Limitations in Market Access and National Treatment, which may vary depending on the sub sectors and the four trading modes; and c) Horizontal commitments, which are transversal to the sectorial commitments. The basic premise is that the higher the number of limitations in the lists of commitments - see each of the items mentioned- the lower the degree of trade opening.

The formula to calculate EduGATS considers that, in terms of Market Access, six limitations may be included (see note 5). Therefore, for each sub sector (y), we will have $\mathrm{MAx}=(6-\mathrm{L}) / 6$ (where $\mathrm{x}$ makes reference to each trade mode and $\mathrm{L}$ is the number of

\footnotetext{
${ }^{13}$ The information needed to measure EduGATS is found in the lists of commitments on liberalisation, which are in the public domain. Once the negotiating rounds are finished, the resulting lists of commitments are annexed to the GATS text and, consequently form part of the agreement. These lists may be consulted by accessing the services database of the WTO (http://tsdb.wto.org/wto/WTOHomepublic.htm).
} 
limitations established, including those present in the horizontal commitments). Additionally, we consider that there could be eight possible limitations in National Treatment ${ }^{14}$ so that $\mathrm{NTx}=(8-\mathrm{L}) / 8$. EduGATS is the result of adding both factors. Once weighted, this may have a value between 0 (not open) and 1 (maximum openness).

$$
\text { EduGATS }=\Sigma_{\mathrm{y}}\left(\mathrm{MA}_{\mathrm{x}}\right)+\Sigma_{\mathrm{y}}\left(\mathrm{NT}_{\mathrm{x}}\right)
$$

EduGATS is a more precise measurement than other indexes, such as those used by the WTO and the OECD, by which to calculate the degree of the commitments. ${ }^{15}$ In their reports on the results of GATS negotiations, the WTO and the OECD usually refer to the number of sub sectors committed as a main indicator (OECD 2002b; WTO 2005b). The imprecision of this criterion is made plain when we examine, for example, the lists of commitments for Japan and Haiti. Japan has established commitments in four educational subsectors; Haiti in one. Therefore, the reports of the WTO and the OECD (Graph 1) decide that Japan has made much deeper commitments than Haiti, with a relation of $4: 1$. Nevertheless, Japan has included many limitations in each subsector so that, according to our calculations (Graph 2), the level of liberalisation on education from Japan has a value of 0.201 . For its part, Haiti has only included one in the list, but with no limitation, so that the value of its commitment is 0.2 . In contrast to the thesis of the WTO/OECD, the degree of commitment of the two countries is very similar.

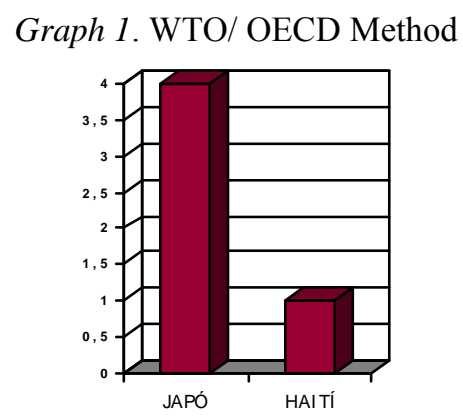

Graph 2. Results according to EduGATS

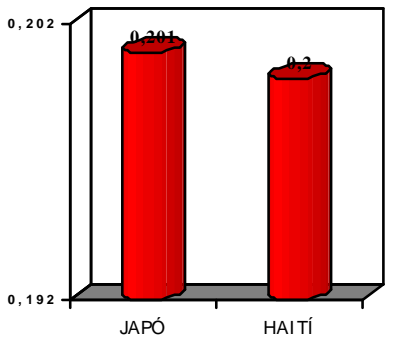

\section{Factors of educational liberalisation. Analysis of consolidated commitments}

To date, 47 member countries have included education in their lists of commitments, which means that most of the members of the WTO have not liberalised education in

\footnotetext{
14 The number of NT limitations is unlimited, but we choose the 'eight' figure for an analytical convenience. There are some arguments for this choice. First, 'eight' is the number of limitations pointed out by the Secretariat in their policy papers (WTO 2002). Second, the Members have never introduced more than 8 limitations in NT commitments; then, we consider than this figure is appropriate for our calculations because the EduGATS value should not be higher than one. Finally, if we set a higher figure, NT commitments would be unbalanced in relation to MA commitments.

${ }^{15}$ Nevertheless, we are aware of some limitations of this new index. For instance, we are attributing the same value to limitations with very different implications, or we do not take into account the fact that the practical significance of the same limitation varies enormously across the different commercial modes.
} 
the GATS framework ${ }^{16}$. But this is not the situation in the totality of the service sectors contemplated by the Agreement, as there are sectors that have been widely liberalised, such as tourism and travel services - commitments made by 129 member countries - or financial services - commitments made by 107 countries $^{17}$.

In order to understand the reasons why liberalisation in education advances more slowly than in other sectors, we have to take into account that education and, for example, health or water supply are sectors in which the state provision normally predominates and which are fundamental services for the effective implementation of a series of social rights. In the educational sector, the liberalisation commitments are especially transcendent due to the direct and indirect effects of trade liberalisation in the education field. We refer here to effects such as the introduction of limitations on state regulation in various areas of the educational policy (Robertson, Bonal \& Dale 2002; Robertson \& Dale 2003), as regards the extension of the private educational sector (Caplan 2003; Feldfeber \& Saforcada 2005; García-Guadilla 2003c; Ginsburg et al. 2003); the accentuation of brain drain (Knight 2003; Wende 2003) or alteration to educational quality (Knight 2002; Rodrigues Dias 2002). Consequently, in the framework of the GATS negotiations, education is considered a "sensitive sector". In fact, some governments, normally progressive and often under pressure from the civil society, have stated publicly that they will not liberalise these kinds of services. ${ }^{18}$

Nevertheless, in spite of there being elements that hinder liberalisation in common to all member countries, the results of the negotiations in the area of educational services vary widely between members. In order to examine this variation in the behaviour of countries in GATS negotiations, we now analyse the factors associated with the liberalisation of educational services. As stated in our lines of hypotheses, we will focus on three factors: the characteristics and needs of the member countries' educational systems (hypothesis 1); the countries' degree of development (hypothesis 2) and the date of joining the WTO (hypothesis 3).

The first hypothesis is mainly inspired by a research realised by Mundy and Iga (2003) that tries to relate GATS commitments to different features and needs of the education systems of the member countries. This independent variable is also present in other papers that try to contrast the 'education rationale' displayed during the GATS negotiations, as well as in other transnationalisation of education policy projects (Iga

\footnotetext{
${ }^{16}$ Specifically, and after health care, educational services is the sector in which the members of WTO have established the fewest commitments on liberalisation.

${ }^{17}$ In these figures, we include the EU (or European Communities) as a single member - that is, the member countries are not included separately. On occasions, the WTO service database deals with the EU-12 and the EU-15 separately.

${ }^{18}$ A multiplicity of players (local governments, representatives of public universities, the student movement, teaching unions etc.), have expressed demands to their governments not to liberalise the educational sector in GATS negotiations (AUCC et al. 2001; Sussex 2005b; Verger \& Bonal 2006). Additionally, some of these campaigns have had an apparently strong impact on state policy in countries such as Canada, Brazil and Argentina (IE-AL 2004; Kachur 2003).
} 
2002; Larsen, Momii \& Vincent-Lancrin 2004; Vlk 2006). The second hypothesis is based in the North-South divide approach, which is so common in the analysis of the WTO outcomes. Several authors usually assume or argue that the North-South divide is a key factor to understand the interests, the bargaining capabilities and the results of the different WTO agreements (Hoekman \& Martin 2001; Narlikar 2001; Smith 2004). The last hypothesis is not based in the established literature. We decided to contrast the relation between the accession date to WTO and the liberalisation commitments inductively and, specifically, after having read the accession rules of this international organisation. We though that these rules, for the reasons we will explain later, could easily conduct to candidate Members to a high level of services liberalisation.

\section{Influence of educational-systems characteristics}

In this first section, we look at the influence of several characteristics within educational systems on the acquisition and intensity of commitments to liberalisation by member countries ${ }^{19}$. The relationship between both elements was put forward and analysed previously by Mundy and Iga (2003). Specifically, these authors examine the relationship between private share of education spending and the intensity of commitments established on education within the GATS framework. As a result of their examination, they conclude that the relationship between the two variables is significant. ${ }^{20}$ In contrast, in our analysis - although we use the same data as Mundy and Iga on the privatisation of financing (OECD 2001) and we focus on the same sample of countries $^{21}$ - we find that the private share of education spending is not associated with the result of GATS negotiations $(\mathrm{P}=0,516)$. This discrepancy can be attributed to our use of a different method when measuring the degree of commitment to liberalisation. The calculation made by Mundy and Iga contemplates the possibility that countries can establish total or partial commitments in the different sub sectors, thus attributing a score midway between total liberalisation and non-liberalisation. ${ }^{22}$ This is an improvement on the method used by the WTO and the OECD, which, as we pointed out above, only takes into account whether countries establish commitments or not in the various sub sectors. Nevertheless, as we have already justified, the typology of limitations that may be introduced when establishing commitments is much wider. Therefore, although Mundy and Iga introduce precision in the calculation of the degree

\footnotetext{
19 The information on levels of privatisation of educational systems and trade of educational services can be found in the data bases of UNESCO's Institute of Educational Statistics and in the Education at a Glance reports from the OECD.

${ }^{20}$ Statistical significance obtained is $P=0.003$.

${ }^{21}$ The data source is OECD (2001), and all the WTO Members that have established commitments in the educational sector compose the sample.

${ }^{22}$ Specifically, the numerical values with which they indicate the intensity of commitments are 2 (total commitment), 1 (partial) and 0 (no commitment established).
} 
of liberalisation with respect to previous methods, their calculations fail to capture the degree of intensity of commitments as effectively as this is reflected by EduGATS ${ }^{23}$.

While the private share of education spending does not correlate with the results of GATS negotiations in the educational sector, there are other variables related to the characteristics of the educational systems that do maintain a more significant relationship. We refer here to the enrolment share in the private sector and to the percentage of State subsidies that the private sector receives at the level of Higher Education $^{24}$. Both factors are associated with the establishment of commitments in education (see the two graphs below), but not with the degree of these commitments ${ }^{25}$.

Graph 3. Commitments depending on the weight of the private sector (left)

Graph 4. Commitments depending on state subsidies to the private sector

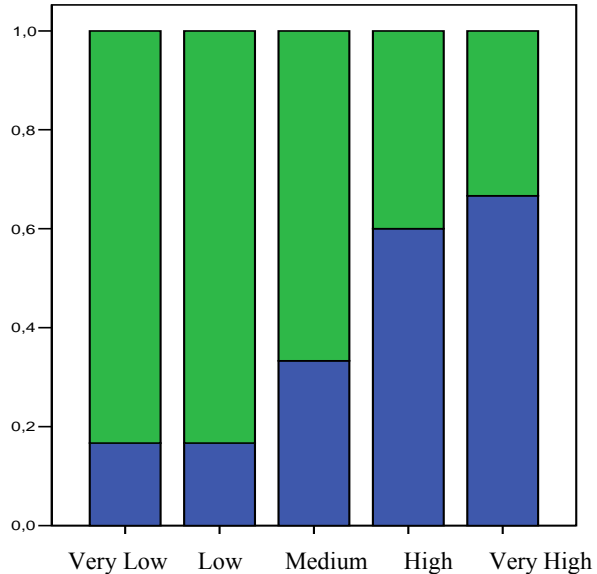

Weight of the private sector

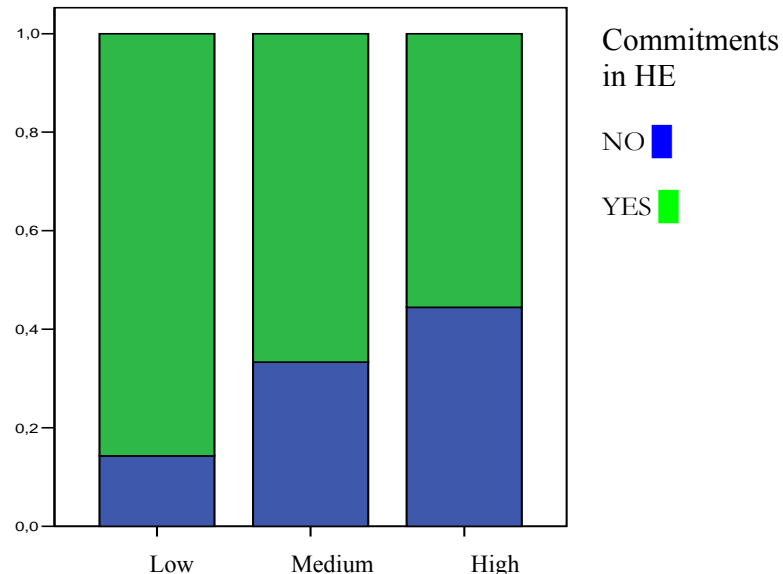

Level of state subsidies to the private sector

In Graph 3, we see how the larger the presence of the private sector in higher education in a country is associated with a lower frequency of establishment of commitments in the educational sector. This may be due to the fact that governments believe the domestic educational supply (state and private) to be sufficiently wide and, consequently, deem it unnecessary to facilitate the entrance of foreign suppliers into their educational systems by means of GATS. Another plausible explanation is that, due to its strong position, the private sector has the ability to bring pressure to bear on governments so that they do not liberalise education in the framework of GATS and

\footnotetext{
${ }^{23}$ For methodological reasons, Mundy and Iga's study also arrives at different conclusions to ours in other issues. For example, the statistical calculations made by Mundy and Iga lead them to underestimate the variable of economic development on the intensity of commitments. Specifically they use a statistical correlation through which they conclude that "advanced industrial countries, countries in transition, and developing countries are distributed randomly (as regards the degree of commitments on liberalisation in education in these countries)" (p. 293). While it is true that the variable economic development is not related so significantly with the intensity of commitments, it is so with the establishment/nonestablishment of commitments (see graph 5).

${ }^{24}$ There is no relation in other educational levels.

${ }^{25}$ Both variables have quantitative values, but in order to ensure greater viability of statistical analysis, we have converted these into qualitative variables.
} 
therefore avoid having to compete with foreign suppliers. ${ }^{26}$ Second, as can be seen in Graph 4, those countries that provide more subsidies to the private sector acquire fewer commitments. This relationship may indicate that those countries that subsidise heavily the private (domestic) sector are not ready to apply the same rules on subsidies to foreign educational centres. Additionally it would be plausible to consider, once again, the pressure brought to bear by the private sector, which would be biased towards nonliberalisation and would be motivated by the fact that private centres are not willing to "share the cake" of state financing with foreign suppliers.

\section{Influence of countries' degree of development}

Probably the most influential factor in our model of analysis on the results of GATS negotiations is the economic development of member countries. Here our analysis shows that the variable "degree of development" is correlated positively with the establishment of commitments on liberalisation in the educational sector. Specifically, as shown in Graph 5, the Southern countries - Developing Countries (DCs) and LessDeveloped Countries (LDCs)- are more reticent to establish commitments in the area of educational services than are the Northern countries - Now-Developed Countries (NDCs) and Transition Countries (TCs). Attribution within each category can be consulted in annex $1^{27}$.

Graph 5. Commitments on education, depending on degree of economic development

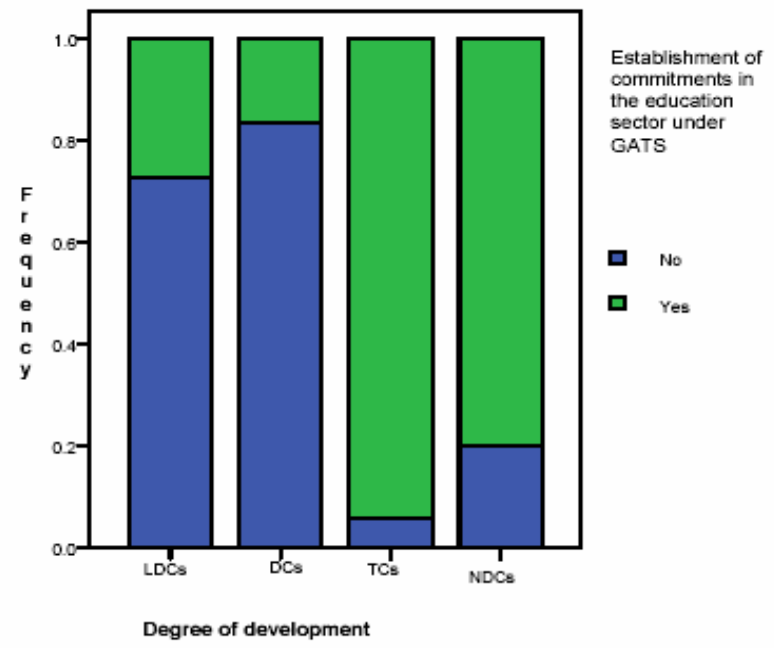

Furthermore, when the Southern countries establish commitments in the educational sector, they usually do so with less intensity. This idea is reflected in Graph 6 , which contains information on the interval of the EduGATS index for each member

\footnotetext{
${ }^{26}$ Regarding this issue, (Mundy \& Iga 2003) document that the lobby of private universities in the US is very active and effective when exercising pressure on Congress not to liberalise the higher education sector.

${ }^{27}$ These are the categories of economic development adopted by the WTO on its Services Database.
} 
country of the WTO. The exact value of EduGATS for each country can be consulted in appendix 1.

Graph 6. EduGATS of member countries of the WTO

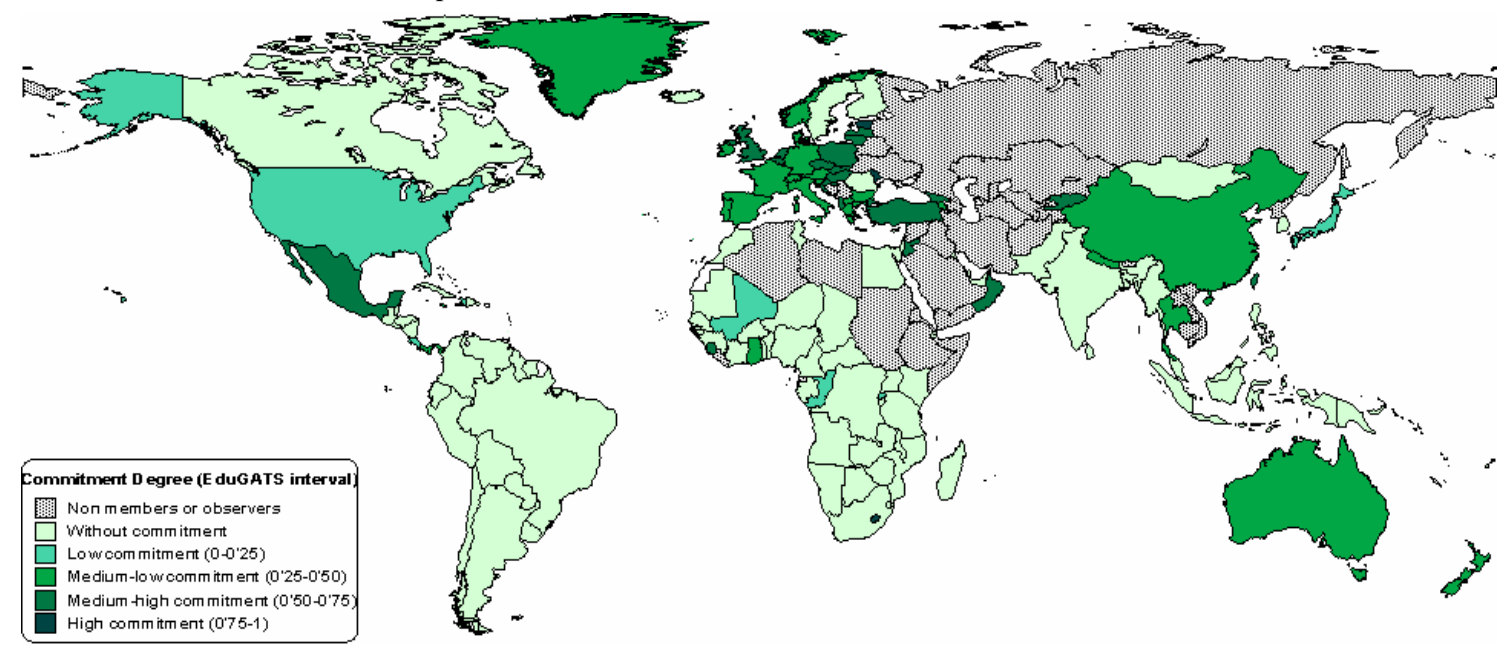

The same data can be analysed by introducing the 'modes of supply' variable. In this case it is evident that, as Graph 7 shows, trade openness is not homogenous between the various modes of supply. Specifically, with respect to mode 4, commitments are undertaken less intensely as compared with the other modes. What is more, it is the only mode for which the developed countries are less 'liberal' than the rest. To a large extent, this can be explained by the fact that rich countries consider establishing commitments in mode 4 to be incompatible with their immigration policies (Saner \& Fasel 2003) ${ }^{28}$. In contrast, mode 4 is the mode for which many Southern countries would like to see more advances, as they consider that their comparative advantage in the trade in services mainly lies in the export of "human resources" (UNCTAD 2005). Specifically, the interest of the Southern countries in this trade mode is in the income they receive from transfers made by their workers abroad (Shashikant 2005).

Graph 7. EduGATS depending on modes of supply

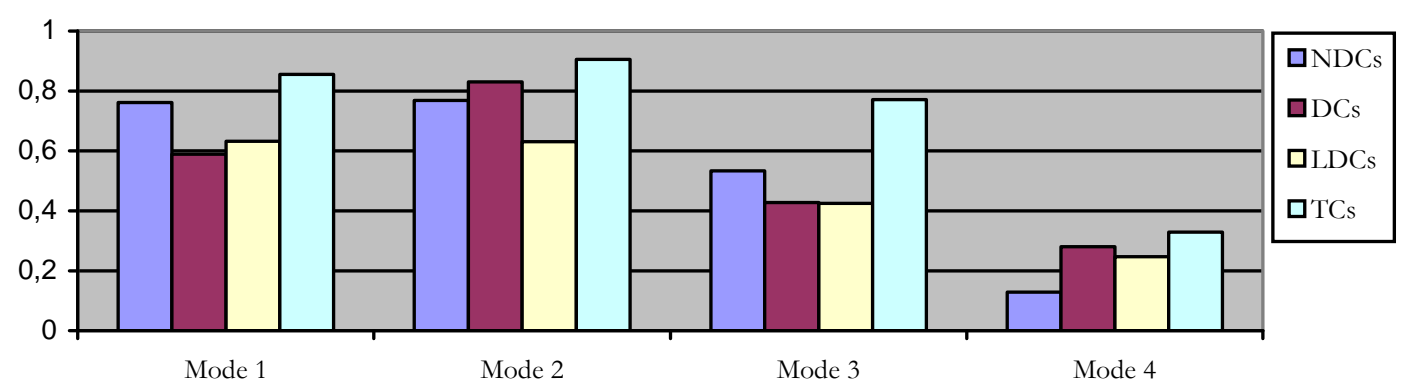

According to interviews with trade negotiators from Southern countries, GATS is

\footnotetext{
${ }^{28}$ This is illustrated by a document from the Spanish Ministry of Trade which refers to the "fear of an increase in the number of foreigners that will lead to an increase in unemployment" in the event that commitments are established in mode 4 (MITC 2004).
} 
perceived, on occasions, as a suitable instrument to attract direct investment and expertise to educational systems, especially for those educational levels that are underfinanced by the state. That is, GATS can be a market solution for the limitation on state investment in education. Nevertheless, as we show in this section, most of the Southern countries opt for non-liberalisation within the educational sector - or for a timid opening up. Therefore it is plausible to assume that the delegations from Southern countries also perceive "threats" or drawbacks in opening up trade within their educational systems. One of the main drawbacks would be related to the fact that the less-developed countries are less competitive in international trade in services (UNCTAD 2005). Educational services would not be an exception to this rule, as most of the Southern countries are almost net importers of education (OECD 2002). Consequently, educational centres in many of these countries not only have great difficulties in accessing global educational markets, but trade liberalisation may also mean that they are expelled from their own markets by the foreign competition (Aboites 2003; Barrow, Didou-Aupetit \& Mallea 2003; Rodríguez Gómez 2004). Additionally, many Southern countries are also aware that trade liberalisation as envisaged in GATS may introduce considerable complexity - as well as limitations - into the area of the domestic regulation and financing of educational systems (Malo 2003). Finally, the lessdeveloped countries do not have suitable legal and technical mechanisms to evaluate the quality of international (or domestic) educational centres. GATS liberalisation commitments, as well as the Domestic Regulation disciplines, could difficult the settlement of this kind of quality education standards. This is an issue specially sensitive because the internationalisation of education in many Southern countries has often led to the multiplication of "diploma-mills" or "garage-universities" (Carnoy 1999; GarcíaGuadilla 2002), terms that point to the low quality of the services provided.

Notwithstanding this, however, the North-South perspective seems appropriate when analysing the liberalisation of educational services in the WTO framework, due to other factors. We refer here to the fact that many Southern countries condition their offers of services on the outcome of negotiations concerning other issues included in the competences of the WTO, in which the developing countries have more offensive interests (agriculture, cotton, textiles, etc.). Guided by this logic, some delegations that have not liberalised education recognise that the educational sector might become 'a bargaining chip' during negotiations.

In short, from the perspective of the less-developed countries, educational liberalisation within the GATS framework may bring more risks and drawbacks than advantages. Hence these countries tend to adopt a defensive attitude when negotiating this issue. To a large extent, this would explain the evident gap between commitments on educational liberalisation between Northern and Southern countries. In any event, many Southern countries may have opted for liberalisation or have considered 
liberalisation in education in exchange for other countries liberalising sectors or areas in which they have more offensive interests.

\section{WTO sign-up date}

Up to the present, most of the member countries of the WTO with commitments on liberalisation within the field of education acquired these during the Uruguay Round (1986-1994). In that round, 28 countries opted for liberalisation, to a greater or lesser degree, of their educational sector. Currently, although the round of negotiations on services that has followed the Uruguay Round, the Doha Round, is still unfinished, there are 47 countries that have established these types of commitments. This increase may have occurred due to the fact that, at any moment and irrespective of the outcome of the rounds, member countries may introduce new commitments in their lists. Nevertheless, it should also be taken into account that not all the countries presently members of the WTO took part in the Uruguay Round. Specifically, only 76 countries were members of the WTO from its outset (January 1 1995), while the current number of members is 149. Hence a large percentage of members have joined since its foundation.

This data make it plausible to consider the possibility that members joining the WTO after the Uruguay Round have liberalised the educational sector more often than has been the case for WTO founder members.

Graph 8. Frequency of commitments depending on WTO sign-up date
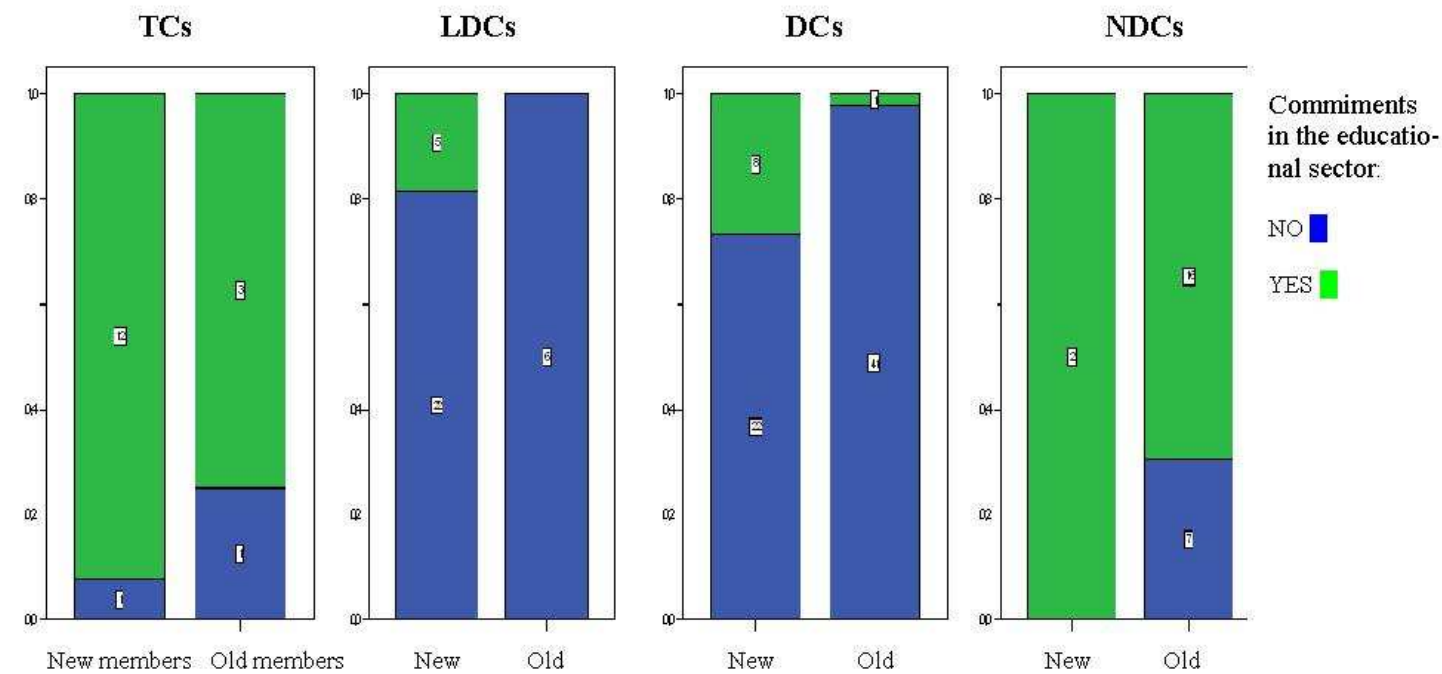

Effectively, as can be seen in Graph 8, those countries that joined the WTO at a later stage have acquired commitments on education more frequently ${ }^{29}$. This is explained by the fact that the process of joining the WTO means that countries aspiring

\footnotetext{
${ }^{29}$ This relationship is also tested in terms of intensity of commitments
} 
to full membership have to adopt a substantial package of liberalising measures. Article XII of the Marrakech agreement sets out that any state or custom union "may adhere to this Agreement in conditions that are considered appropriate by the WTO". In practice, this means that, when a country makes an application to join the WTO, a Working Group is set up to evaluate the candidate's trade policies and to put forward the sectors that require liberalisation for full membership of the WTO to be granted. To understand the implications of this process, we must take into account that the working groups are not made up of technocrats but rather of delegates from member countries. These delegates bring pressure to bear on the candidate country to liberalise sectors in which their countries have offensive interests. Each member of the working group can effectively veto the accession if it does not secure the commitments it wants. Hence the adhesion process is not a procedure established ex ante; it is, like almost all the activity carried out at the WTO, a negotiation process. ${ }^{30}$ Once negotiations between the candidate country and the Working Group have finalised, a draft Protocol of Accession is passed to the Ministerial Conference of the WTO, which is the body with the competence to formally decide whether the adhesion will go ahead (Suranovic 1998).

In short, the accession process to the WTO reveals that most of the new members were, at the time of joining, externally conditioned to liberalise various sectors within their economy. In all likelihood, this is also applicable to their services ${ }^{31}$. The confirmation of this hypothesis shows us that liberalisation in services sectors such as education was conditioned as much by institutional factors (such as, in this case, the WTO rules on the accession of new members) as by strategies related to educational aspects. This observation may at least partially be understood as a logical consequence of the fact that the ministries of education in member countries do not participate formally in the GATS negotiations, although these are related to the sector for which, theoretically, they have the main regulatory competences ${ }^{32}$.

\section{Conclusions}

This article analyses the rationale of the trade liberalisation in the educational sector within the GATS framework. Several sources reflect that there are several factors that serve as a disincentive to WTO member-country governments to liberalise the educational sector in the framework of the Agreement. Among other factors, we refer to

\footnotetext{
${ }^{30}$ Interestingly, the working party members conduct the negotiation; but the candidate has usually a passive role.

${ }^{31}$ It should be noted that the relationship is weaker in the case of the LDCs. Specifically, we have shown that $81.81 \%$ of these countries are new members of the WTO, but have established commitments in education as frequently as, for example, transition countries (most of whom are also new members). The reason is that the LDCs have more favourable and flexible WTO access conditions than other countries (OMC 2003) and, therefore are not subject to the same pressure to open up their markets.

${ }^{32}$ Delegations are usually made up of civil servants from the ministries of trade and/or foreign affairs of the member countries.
} 
limits on state regulation that go hand in hand with the establishment of commitments, or to the fact that opening up trade in education is a policy opposed by many influential sectors in society. Nevertheless, from our research we find that there is a cluster of countries that are more reticent to liberalise than others; this is made up of the LessDeveloped Countries and the Developing Countries. These countries do not generally have offensive interests in the liberalisation of the educational-services sector as their educational industry could hardly be expected to be able to penetrate a highly liberalised global educational market. Furthermore, the education services liberalisation is more sensitive in the Southern countries for reasons such as the weakness of their current regulation in this area or because their educational centres, when faced with international competition, would undergo an erosion of the capacity for intervention within their own territories.

Our analysis also highlights that certain characteristics of the educational systems are not related (at least in a way that can be globally extrapolated) with the results of the GATS negotiations. At the same time, apparently unrelated variables to educational aspects are more strongly associated. One of them is related to the accession process of the WTO, which force the candidate members to adopt an ambitious liberalisation package. Another non-educational reason is that, as some interviewed negotiators recognise, education could become a "bargaining chip" during the negotiating process. This implies that the opening up of trade within the educational sector depends on the outcome of negotiations on other issues dealt with at the WTO agriculture, raw materials, industrial goods, etc.

While our work provides elements for a fuller understanding of the liberalisation process of the educational sector in the GATS framework, there are still many questions to be answered. The statistical tools have been useful to contrast the level of association of some factors to the educational liberalisation in the framework of GATS, but a new strategy is needed to study in depth the liberalisation rationale. Future analysis should introduce mediator variables between countries features and its behaviour. We refer, for instance, to more subjective factors such as the ideas, principles, causal beliefs, values and perceptions of the actors that are involved in the negotiations process. To contrast the explanatory weight of these new variables, it would be useful to combine this statistical approach with a qualitative case studies strategy.

\section{Bibliography}

Aboites, H. (2003). "Derecho a la educación o mercancía: La experiencia de diez años de libre comercio en la educación mexicana", Foro Libre Comercio y Educación. México DF, 08/09/03-09/09/03: Coalición Trinacional en Defensa de la Educación Pública. 
Abugattas, L. 2006. "Domestic Regulation and the GATS: Challenges for Developing Countries." ICTSD Polict Paper (draft) www.ictsd.org/dlogue/2006-02-28/celli.pdf, 13/03/07.

AUCC, ACE, EUA, \& CHEA (2001). "Joint Declaration about HE and the GATS". http://www.aic.lv/ace/gats/jointdec.html, 23/07/05

Barrow, C. W., Didou-Aupetit, S., \& Mallea, J. (2003). Globalisation, Trade Liberalisation, and Higher Education in North America: The Emergence of a new market under NAFTA? Dordrecht: Kluwer Academic Publishers.

Caplan, R. (2003). "GATS: in whose service?" Nexus Magazine, 8, 3, www.nexusmagazine.com/backissues/0803.conts.html, 06/05/04

Carnoy, M. (1999). "Globalización y reestructuración de la educación". Revista de Educación, $318,145-162$.

Drake, W. J. and K. Nicolaidis (1992). "Ideas, Interests, and Institutionalization: "Trade in Services" and the Uruguay Round." International Organization 46, 1: 37-100.

Feldfeber, M., \& Saforcada, F. (2005). "Libre comercio y Educación Superior en América Latina. Notas sobre el caso argentino". Foro Latinoamericano de Políticas Educativas, III Foro Virtual, El Tratado de Libre Comercio y sus Implicancias en la Educación Superior en América Latina, www.foro-latino.org/fv3.htm, 06/03/05

Francois, J., \& Wooton, I. (2000). "Market Structure, trade Liberalisation and the GATS". Centre for International Economic Studies. Policy Discussion Paper, 3.

García-Guadilla, C. (2002). "General Agreement of Trade in Services, Higher Education and Latin America", Paper prepared for the Convention of Universities Members of Columbus. Paris, July 2002.

- (2003). "Educación superior y AGCS. Interrogantes para el caso de América Latina". In C. García-Guadilla (Ed.), El difícil equilibrio. La educación superior como bien público y comercio de servicios. Caracas: Editorial Latina.

Ginsburg, M., Espinoza, O., Popa, S., \& Terano, M. (2003). "Privatisation, Domestic Marketisation and International Commercialisation of Higher Education: vulnerabilities and opprtunities for Chile and Romania within the framework of WTO/GATS". Globalisation, Societies and Education, 1, 3, 413-445.

Gould, E. (2004). "The US-Gambling Decision. A Wakeup Call for WTO Members". CCPA Briefing Paper. Trade and Investment Series, 5, 4.

Iga, M. (2002). "International Trade in Education Services Under the World Trade Organization: Why do nations seek to create an international trade system for education?", Thesis report of the International and Comparative Education School of Education. Stanford: Stanford University.

IE-AL (2004). "Declaración de Brasilia", Ministros de Educación de Argentina y Brasil se comprometen a no liberalizar la educación conforme se establece en el AGCS. San Pedro, Costa Rica: Internacional de la Educación. Oficina Regional para América Latina.

Jawara, F., \& Kwa, A. (2004). Behind the scenes at the WTO: the real world of international trade negotiations. Lessons of Cancun. London-New York: Zed Books.

Kachur, J. L. (2003). "Whose Intellectual Property? Whose Rights? GATS, TRIPS and Education in Canada". Globalisation, Societies and Education, 1, 3, 375-411.

Khor, M. (2005). "GATS negotiators debate "crisis" in WTO services talks". TWN Info Service on WTO and Trade Issues, 199, www.twnside.org.sg/title2/twninfo199.htm.

- (2005b). "Developing Countries voice objections to 'benchmarking' proposals in services". TWN Info Service on WTO and Trade Issues, 259, www.twnside.org.sg/title2/twninfo259.htm.

Knight, J. (2002). "Trade in Higher Education Services: The Implications of GATS". March 2002,www.obhe.ac.uk 19/03/05

— (2003). "GATS, Trade and Higher Education Perspective 2003-Where are we?" London: The Observatory on Borderless Higher Education.

Larsen, K., Martin, J. P., \& Morris, R. (2002). "Trade in Educational Services: Trends and Emerging Issues". The World Economy, 25, 6, 849-868.

Larsen, K., Momii, K. \& Vincent-Lancrin, S. (2004). "Cross-border Higher Education: an analysis of current trends, policy strategies and future scenarios." OBHE Report November 2004. 
Malo, S. (2003). "La comercialización de la educación superior". In C. García-Guadilla (Ed.), El difícil equilibrio. La educación superior como bien público y comercio de servicios. Caracas: Editorial Latina.

MITC (2004). "Guía para la lectura y valoración de los compromisos y las ofertas en el marco del AGCS". Ministerio de Industria, de Turismo y de Comercio del Reino de España, 11/06/04.

Mundy, K., \& Iga, M. (2003). "Hegemonic Exceptionalism and Legitimating Bet-Hedging: paradoxes and lessos from the US and Japanese approaches to education services under the GATS". Globalisation, Societies and Education, 1, 3, 321-357.

Nielson, J. (2003). "A Quick Guide to the State of Play in the GATS Negotiations", Forum on Trade in Educational Services. Trondheim (Norway), 03/11/03-04/11/03 OECD.

OECD (2001). Education at a Glance 2001. Paris: OECD.

OECD (2002). "Indicators on Internationalisation and Trade of Post-secondary Education", OECD/US Forum on Trade in Educational Services. Washington DC, 23/05/02-24/05/02.

- (2002b). "Current Commitments under the GATS in Educational Services", OECD/US Forum on Trade in Education Services Washington DC, 23/05/02-24/05/02.

OMC (1999). Introducción al Acuedo General sobre el Comercio de Servicios (AGCS). Ginebra: División del Comercio de Servicios de la OMC.

- (2001). Con el comercio hacia el futuro. Ginebra: OMC.

- (2003). Entender la OMC. Ginebra: OMC.

Robertson, S., Bonal, X., \& Dale, R. (2002). "GATS and the education services industry: the politics of scale and global reterritorialization". Comparative Education Review, 46, 4, 472496.

Robertson, S., \& Dale, R. (2003). "This is what the fuss is about! The implications of GATS for education systems in the North and the South", UK Forum for International Education and Training. 29/05/03: Commonwealth Secretariat.

- (2003b). "Changing Geographies of Power in Education: the politics of rescaling and its contradictions". GENIE - the Globalisation and Europeanisation Network in Education, online papers, www.genie-tn.net, 12/03/05

Rodrigues Dias, M. A. (2002). "Utopía y comercialización en la educación superior del s. XXI". In M. A. Rodrigues Dias (Ed.), Lecciones de la Conferencia Mundial sobre Educación Superior-Perspectivas de la Educación Superior en el s. XXI. Buenos Aires: Siglo XXI.

Rodríguez Gómez, R. (2004). "Inversión Extranjera Directa en Educación Superior. El caso de México". Revista Educación Superior, 33, 2.

Saner, R., \& Fasel, S. (2003). "Negotiating Trade in Educational Services within the WTO/GATS context". Aussenwirtschaft, 11, 257-308.

Shashikant, S. (2005). "GATS talks will move only with a "big leap" in mode 4". TWN Info Service on WTO and Trade Issues, 198, www.twnside.org.sg/title2/twninfo198.htm, 17/03/05

Suranovic, S. (1998). A Three-Year Review of the World Trade Organization, The International Economics Study Center, http://www.internationalecon.com/wto, 12/05/05

Sussex, E. (2005). "Local and Regional Reaction to GATS and Similar Trade Rules". 4th draft, $26 / 07 / 05$.

UNCTAD (2005). "Trade in Services and Development Implications". TD/B/COM.1/71, http://www.unctad.org/en/docs/c1d71 en.pdf 12/05/05

Vlk, A. (2006). Higher Education and GATS. Regulatory Consequences and Stakeholders' Responses. University of Twente: CHEPS.

Wende, M. C. v. d. (2003). "Globalisation and Access to Higher Education". Journal of Studies in International Education, 7, 2, 193-206.

WTO (2000). Guide to the GATS. An Overview of Issues for Further Liberalization of Trade in Services. The Hague: Kluwer Law International.

- (2005). "Initial and Revised Offers. A factual assesment of the sate of play", http://docsonline.wto.org 27/06/05

- (2005b). "Ministerial Declaration: Ministerial Conference. Sixth Session. Hong Kong, 13 - 18 December 2005". Adopted on 18 December 2005, WT/MIN(05)/DEC. 
- (2006). Measuring Trade in Services. WTO / Inter-agency Task Force on Statistics of International Trade in Services,

http://www.wto.org/English/res_e/statis_e/services training_module_e.pdf, 20/03/07. 
Annex 1: EduGATS (depending on modes of supply)

\begin{tabular}{|c|c|c|c|c|c|}
\hline Countries & Total & Mode 1 & Mode 2 & Mode 3 & Mode 4 \\
\hline Australia & 0,36970 & 0,567 & 0,567 & 0,267 & 0,079 \\
\hline Austria & 0,43250 & 0,550 & 0,550 & 0,550 & 0,080 \\
\hline Japan & 0,20154 & 0,100 & 0,100 & 0,517 & 0,090 \\
\hline Liechtenstein & 0,34570 & 0,350 & 0,350 & 0,566 & 0,116 \\
\hline New Zealand & 0,39675 & 0,512 & 0,512 & 0,475 & 0,087 \\
\hline Norway & 0,44560 & 0,616 & 0,683 & 0,366 & 0,116 \\
\hline Switzerland & 0,40671 & 0,460 & 0,460 & 0,633 & 0,073 \\
\hline US & 0,22910 & 0,292 & 0,292 & 0,300 & 0,033 \\
\hline Belgium & 0,51230 & 0,733 & 0,733 & 0,466 & 0,116 \\
\hline Denmark & 0,49570 & 0,733 & 0,733 & 0,400 & 0,116 \\
\hline France & 0,44978 & 0,683 & 0,733 & 0,266 & 0,116 \\
\hline Germany & 0,49980 & 0,733 & 0,733 & 0,416 & 0,116 \\
\hline Greece & 0,48528 & 0,733 & 0,733 & 0,358 & 0,116 \\
\hline Ireland & 0,49980 & 0,733 & 0,733 & 0,416 & 0,116 \\
\hline Italy & 0,48528 & 0,733 & 0,733 & 0,358 & 0,116 \\
\hline Luxembourg & 0,51230 & 0,733 & 0,733 & 0,466 & 0,116 \\
\hline Netherlands & 0,51230 & 0,733 & 0,733 & 0,466 & 0,116 \\
\hline Portugal & 0,49570 & 0,733 & 0,733 & 0,400 & 0,116 \\
\hline Spain & 0,49258 & 0,733 & 0,733 & 0,388 & 0,116 \\
\hline UK & 0,51230 & 0,733 & 0,733 & 0,466 & 0,116 \\
\hline NDCs average & 0,43721 & 0,610 & 0,616 & 0,427 & 0,104 \\
\hline China & 0,42175 & 0,000 & 1,000 & 0,167 & 0,521 \\
\hline Taiwan & 0,52728 & 0,750 & 0,750 & 0,500 & 0,109 \\
\hline Costa Rica & 0,13848 & 0,000 & 0,400 & 0,067 & 0,087 \\
\hline Ghana & 0,37500 & 0,400 & 0,400 & 0,400 & 0,300 \\
\hline Jamaica & 0,49893 & 0,600 & 0,600 & 0,496 & 0,300 \\
\hline Jordan & 0,55713 & 0,563 & 0,938 & 0,583 & 0,146 \\
\hline Mexico & 0,56660 & 0,800 & 0,800 & 0,550 & 0,116 \\
\hline Oman & 0,55410 & 0,800 & 0,800 & 0,500 & 0,116 \\
\hline Panama & 0,34680 & 0,600 & 0,600 & 0,100 & 0,087 \\
\hline Thailand & 0,29058 & 0,100 & 0,600 & 0,462 & 0,000 \\
\hline T\&Tobago & 0,19998 & 0,300 & 0,300 & 0,000 & 0,200 \\
\hline Turkey & 0,63640 & 0,750 & 0,800 & 0,283 & 0,712 \\
\hline DCs av. & 0,42608 & 0,472 & 0,666 & 0,342 & 0,225 \\
\hline Congo & 0,15310 & 0,200 & 0,200 & 0,183 & 0,029 \\
\hline Cambodja & 0,44055 & 0,600 & 0,600 & 0,475 & 0,087 \\
\hline Gambia & 0,45930 & 0,600 & 0,600 & 0,550 & 0,087 \\
\hline Haiti & 0,20000 & 0,200 & 0,200 & 0,200 & 0,200 \\
\hline Lesotho & 0,89575 & 1,000 & 1,000 & 0,833 & 0,750 \\
\hline Mali & 0,20000 & 0,200 & 0,200 & 0,200 & 0,200 \\
\hline Nepal & 0,40613 & 0,563 & 0,550 & 0,425 & 0,087 \\
\hline Rwanda & 0,20000 & 0,200 & 0,200 & 0,200 & 0,200 \\
\hline Sierra Leone & 0,53638 & 1,000 & 1,000 & 0,000 & 0,146 \\
\hline LDCs av. & 0,38791 & 0,507 & 0,506 & 0,341 & 0,199 \\
\hline Albania & 0,70000 & 0,650 & 0,800 & 0,750 & 0,600 \\
\hline Armenia & 0,34580 & 0,400 & 0,400 & 0,375 & 0,208 \\
\hline Bulgaria & 0,30823 & 0,346 & 0,512 & 0,287 & 0,087 \\
\hline Croatia & 0,52493 & 0,533 & 0,750 & 0,550 & 0,266 \\
\hline Czech Rep. & 0,68883 & 0,825 & 0,825 & 0,637 & 0,468 \\
\hline Estonia & 0,75513 & 0,938 & 0,938 & 1,000 & 0,146 \\
\hline Georgia & 0,52485 & 0,717 & 0,717 & 0,550 & 0,116 \\
\hline Hungary & 0,56660 & 0,800 & 0,800 & 0,550 & 0,116 \\
\hline Kyrgyzstan & 0,58320 & 0,683 & 0,800 & 0,733 & 0,116 \\
\hline Latvia & 0,69990 & 0,800 & 0,800 & 0,733 & 0,466 \\
\hline Lithuania & 0,61035 & 0,800 & 0,800 & 0,725 & 0,116 \\
\hline Macedonia & 0,40305 & 0,525 & 0,525 & 0,475 & 0,087 \\
\hline Moldova & 0,88013 & 1,000 & 1,000 & 0,938 & 0,583 \\
\hline Poland & 0,50000 & 0,550 & 0,550 & 0,483 & 0,416 \\
\hline Slovakia & 0,67675 & 0,833 & 0,833 & 0,708 & 0,333 \\
\hline Slovenia & 0,39365 & 0,550 & 0,550 & 0,388 & 0,087 \\
\hline TCs av. & 0,57259 & 0,684 & 0,725 & 0,618 & 0,263 \\
\hline
\end{tabular}


